Reprod. Nutr. Develop., 1988, 28 (3 B), 693-702

\title{
Expression of asymmetric forms of acetylcholinesterase during myogenesis in vitro
}

\author{
J. P. TOUTANT
}

Laboratoire de Physiologie animale, I.N.R.A.,

9, place Viala, 34060 Montpellier Cedex, France.

Summary. Chick muscle cells differentiating in vitro in the absence of nerve cells produce asymmetric forms of acetylcholinesterase (AChE) only if they originate from muscles which accumulate these forms in ovo (i.e. after embryonic day 5). The presence of nerve cells does not induce the synthesis of $A$ forms in cultures of 5 day-old myoblasts and does not increase their proportion in cultures of 7 day-old myoblasts. Thus, the capacity to synthesize (or assembie) the complex polymeric forms of AChE does not reflect a direct neural influence but might rather be considered as an intrinsic property of the "late" categories of myoblasts that sequentially occur during the differentation of leg muscles.

We studied the synthesis of ChE molecular forms in the mouse muscle $C_{2}$ cell line. From these experiments we suggest that the synthesis of $A$ forms (or their assembly) can take place as soon as the cells are withdrawn from the cell cycle, but does not require cell fusion by itself.

These observations are related to other recent studies that challenge the validity of A forms as topographical/physiological markers of neuromuscular interactions.

\section{Introduction.}

Acetylcholinesterase (AChE, EC 3117) of vertebrate skeletal muscle can exist in six molecular forms: three globular forms $G_{1}, G_{2}$ and $G_{4}$ corresponding to monomer, dimer and tetramer of catalytic subunits, and collagen-tailed, asymmetric forms, in which 1, 2 or 3 tetramers of catalytic subunits are associated to a collagenic component that confers their specific hydrodynamic properties to the molecules. These forms are referred to as $A_{4}, A_{8}$ and $A_{12}$ (Bon et al., 1979; Massoulié and Bon, 1982 ; Massoulié and Toutant, 1987).

A forms were found concentrated at rat neuromuscular junctions (Hall and Kelly, 1971; Hall, 1973). They appeared at the moment of innervation in developing muscles (Vigny et al., 1976 ; Koenig and Vigny, 1978), disappeared after denervation and reappeared with reinnervation (Vigny et al., 1976). It was therefore considered that these forms represented topographical markers and physiological correlates of nerve-muscle interactions (Vigny et al., 1976).

In cell cultures it was demonstrated that rat myoblasts removed in utero at embryonic day 14 (i.e. before the innervation of muscle) did not produce $A$ forms. 
They acquired this capacity if they were cocultured with nerve cells originating from the spinal cord (Koenig and Vigny, 1978). It was therefore suggested that the synthesis of $A$ forms was induced by a direct neural influence (review in Toutant and Massoulié, 1987).

We tested this hypothesis in the case of chick muscle cells differentiating in ovo and in vitro (Toutant et al., 1983). Some of the results reported in this paper do not fit with earlier observations in rat and challenge the idea of a neural determination of the expression of AChE asymmetric forms. Other experimental data are also reported concerning the possible relationship between early events of myogenesis (withdrawal from cell cycle, cell fusion) and the synthesis of A forms.

\section{Material and Methods.}

Cell cultures. - A complete description of chick muscle cultures is given in Toutant et al. (1983). Muscle cells were grown in Dulbecco's minimum Eagle medium (DMEM) containing $5 \%$ of fetal calf serum (FCS).

Cultures of $\mathrm{C}_{2}$ cells were obtained from $\mathrm{C}$. Pinset at the Pasteur Institute. Medium conditions were manipulated in order to obtain $\mathrm{C}_{2}$ cells in three different stages of differentiation, as described previously in the case of L6 cells (Pinset and Whalen, 1984, 1985):

Type 1 cultures: cells were cultured for 4 days in Ham's $F_{12}$ medium supplemented with fetal calf serum $(20 \%)$ and $10^{-6} \mathrm{M}$ dexamethasone: in this medium, the $\mathrm{C}_{2}$ cells proliferate.

Type 2 cultures : cells were cultured for 4 days in DMEM + insulin $(10 \mu \mathrm{g} / \mathrm{ml})$ + transferrin without serum, in the presence of $0.2 \mathrm{mM} \mathrm{Ca}^{2+}$. In this medium the cells cease their divisions but do not fuse into myotubes.

Type 3 cultures : cells were cultured for 4 or 7 days in a medium similar to type 2 but the concentration of $\mathrm{Ca}^{2+}$ was increased to $2 \mathrm{mM}$. In these conditions, the $\mathrm{C}_{2}$ cells fuse into multinucleated myotubes.

Tissue homogenization, centrifugation and AChE assay. - These routine operations were performed as indicated in Toutant et al. (1983) and Toutant (1986). Centrifugation parameters are indicated in figure legends.

Collagenase treatment. - The homogenates of cell cultures were subjected to collagenase digestion according to Toutant et al. (1985). 3000 units of collagenase (Advance Biofactures Co., form III) were solubilized in $500 \mu \mathrm{l}$ of $1 \mathrm{M}$ Tris- $\mathrm{HCl}, \mathrm{pH} 8.0$ and $50 \mathrm{mM} \mathrm{CaCl}_{2}$. Incubations $(300 \mu \mathrm{l} \mathrm{extract}+100 \mu \mathrm{l}$ of collagenase solution) were performed at $20^{\circ} \mathrm{C}$ for $1 \mathrm{~h}$ or $2 \mathrm{~h}$ at $37^{\circ} \mathrm{C}$.

\section{Results.}

Synthesis of AChE A forms in chick muscle cultures.

The expression of A forms by chick muscle cells in vitro has been source of conflicting reports (see review in Toutant and Massoulié, 1987). It was demonstrated however that the use of fetal calf serum was a prerequisite for the 
synthesis of A forms in 11 day-old myoblasts cultures (Bulger et al., 1982 ; Toutant et al., 1983) and that horse serum interferes with the analysis of molecular forms in gradient centrifugation (Toutant et al., 1983 ; Vallette et al., 1986).

We compared the proportions of AChE molecular forms produced in cultures seeded with myoblasts removed at embryonic days (ED) 5, 7, 9 and 11. Figure 1 shows that in culture of ED5 myotubes synthesized only the globular forms $G_{1}$, $\mathrm{G}_{2}$ and $\mathrm{G}_{4}$. At ED7, 9 and 11, the $A_{12}$ form (20S) was also detected in addition to $G_{2}$ and $G_{4}$ forms, and represented $3 \%$ (ED7), $9 \%$ (ED9) and $10 \%$ (ED11) of the total activity after six days in culture.

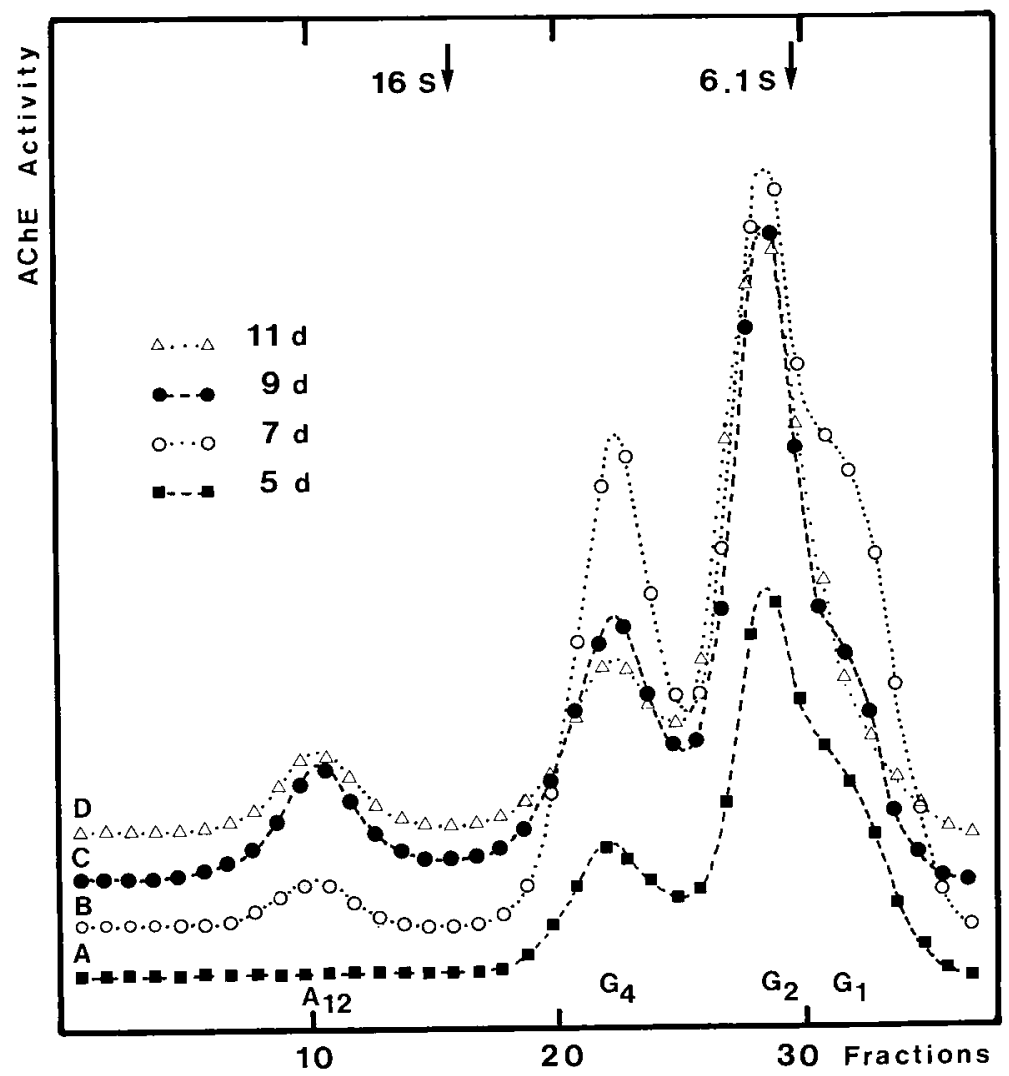

FIG. 1. - Molecular forms of AChE synthesized by chick muscle cel/s in culture. Myoblasts used to initiate the cultures were removed from chick embryos at different ages : A : 5 day-old myoblasts, 6 days in culture. AChE activity: $0.23 \mathrm{OD} / \mathrm{min} / \mathrm{ml}$. No A form, $\mathrm{G}_{1}$ form accounts for $30 \%$ of total activity. $B: 7$ day-old myoblasts, 6 days in culture. Activity : $0.280 D / \mathrm{min} / \mathrm{ml}$. $A_{12}$ form : $3 \% ; G_{1}$ form : $23 \% ; C: 9$ day-old myoblasts, 6 days in culture. Activity: $4.90 D / m i n / m l . A_{12}$ form : $9 \%$; $\mathrm{G}_{1}: 15 \% ; \mathrm{D}: 11$ day-old myoblasts, 6 days in culture. Activity : $2.4 \mathrm{OD} / \mathrm{min} / \mathrm{ml} . \mathrm{A}_{12}: 10 \%$; $\mathrm{G}, 8 \%$.

All cultures were seeded at a density of $2.10^{6}$ cells $/$ dish $(\varnothing=10 \mathrm{~cm})$

Sedimentation analyses were performed in 5-20\% sucrose gradients $(1 \mathrm{M} \mathrm{NaCl}, 1 \%$ Triton $\times 100$ ) centrifuged for $19 \mathrm{~h}$ at $36000 \mathrm{rpm}$ at $4{ }^{\circ} \mathrm{C}$ in a Beckman SW41 rotor. 165: E. coli $\beta$ galactosidase ; $6.1 \mathrm{~S}: E$. coli alkaline phosphatase. 
The A forms of AChE appeared in leg muscles after ED5 in ovo (Toutant et al., 1983) in apparent correlation with the establishment of the first neuromuscular junctions (Landmesser and Morris, 1975). Therefore if seems that "late " myoblasts (ED7, 9 and 11) possess the information necessary to express the $A_{12}$ form. We tested the influence of cocultured nerve cells on "late" and "early " (ED5) myoblasts.

Effect of cocultured nerve cells on $A$ form synthesis in muscle cultures.

Figures 2 and 3 show the effect of cocultured nerve cells on the molecular forms of AChE produced by 7 day-old (2) or 5 day-old chick myoblasts (3).

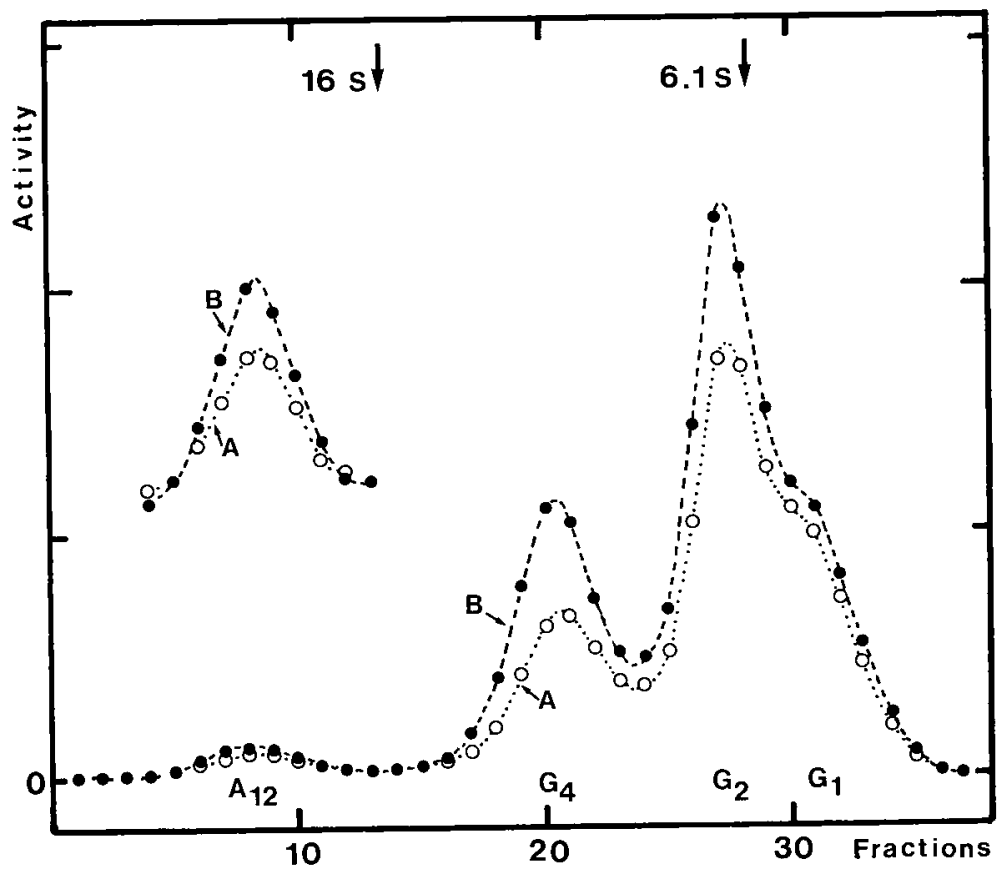

FIG. 2. - AChE molecular forms synthesized in 7 day-old myoblasts cultures. A : Aneural muscle culture : $3.10^{6}$ muscle cells cultured for 6 days. B : Coculture of $3.10^{6}$ myoblasts and $3.10^{6}$ nerve cells from spinal cord of 7 day-old chick embryo for 6 days.

Total AChE activities were $0.36 \mathrm{OD} / \mathrm{min} / \mathrm{dish}$ in $\mathrm{A} ; 1.1 \mathrm{OD} / \mathrm{min} / \mathrm{dish}$ in $\mathrm{B}$.

Centrifugation was performed as in figure 1 . The $20 \mathrm{~S}$ regions of each profile are redrawn with an expanded scale ( $\times 10)$.

In the experiment of figure 2, the total AChE activity in the coculture was $1.1 \mathrm{OD} / \mathrm{min} / \mathrm{ml}$, and the activities of the separate control cultures were $0.36 \mathrm{OD} / \mathrm{min} / \mathrm{ml}$ for the muscle cells and $0.6 \mathrm{OD} / \mathrm{min} / \mathrm{ml}$ for the nerve cells. The activity of the coculture was therefore almost entirely accounted for by the sum 
of the two activities. Figure 2 shows that the proportion of A forms was similar in the coculture and in the aneural muscle cell cultures ( $3 \%$ in each case). A similar

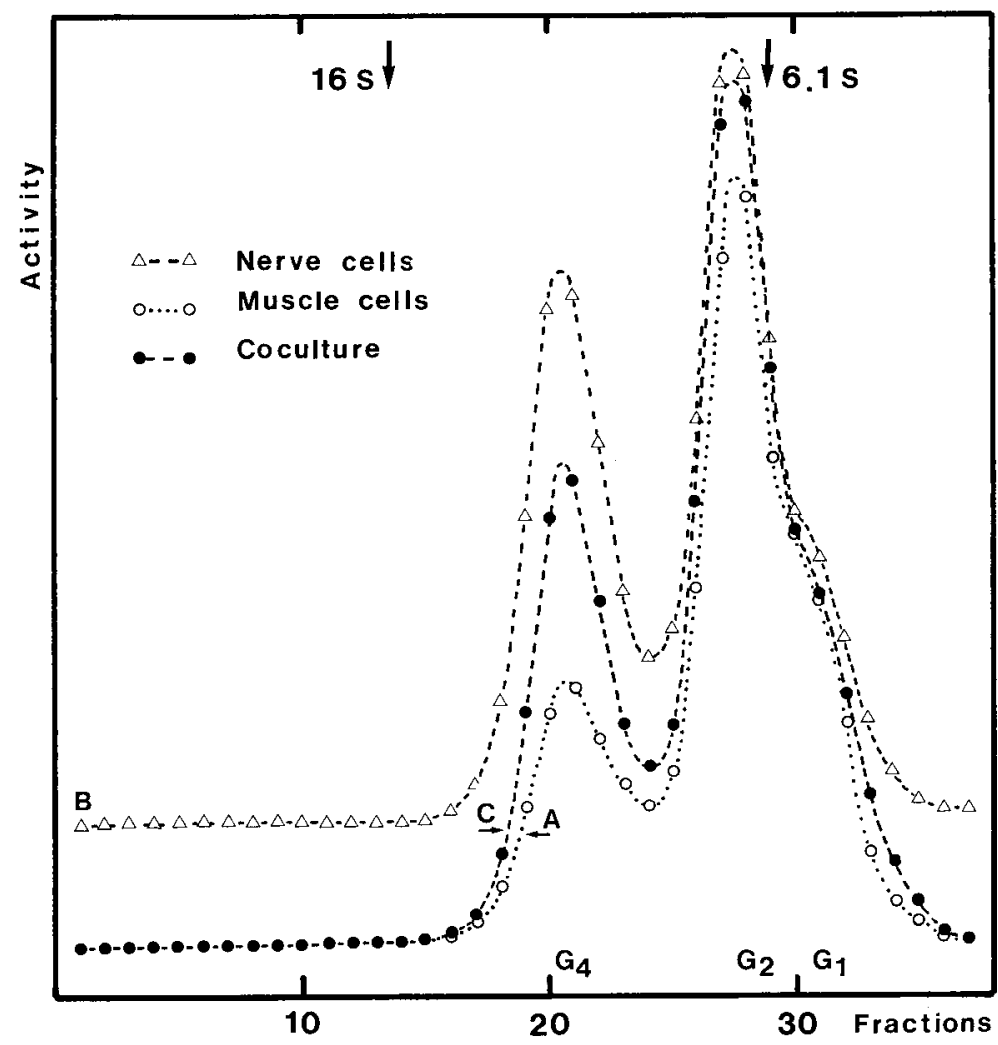

FIG. 3. - AChE molecular forms produced in 5 day-old myoblasts cultures. A : Muscle cells from 5 day-old chick embryo leg muscles : $2.10^{6}$ cells $/$ dish $(=10 \mathrm{~cm}), 6$ days in culture. AChE activity : $0.23 \mathrm{OD} / \mathrm{min} /$ dish. AChE specific activity : $0.1 \mathrm{OD} / \mathrm{min} / \mathrm{mg}$ protein. $\mathrm{B}$ : Nerve cells from 6 day-old chick embryo spinal cord: $2.10^{6}$ cells/dish, 6 days in culture. AChE activity: $0.34 \mathrm{OD} / \mathrm{min} / \mathrm{dish}$. Specific activity: $0.31 \mathrm{OD} / \mathrm{min} / \mathrm{mg}$ protein. $\mathrm{C}$ : Coculture of $2.10^{6}$ muscle cells and $2.10^{6}$ nerve cells. Total AChE activity: $1.05 \mathrm{OD} / \mathrm{min} /$ dish. Specific activity : $0.41 \mathrm{OD} / \mathrm{min} / \mathrm{mg}$ prot.

Cells were homogenized in high salt buffer containing $1 \% \mathrm{~T} \times 100$. The extracts were analyzed in $5-20 \%$ sucrose gradients centrifuged for $19 \mathrm{~h}$ at $36000 \mathrm{rpm}$ in a SW41 rotor.

result was obtained by Kato et al. (1980) using ciliary ganglion cells in coculture with chick muscle cells.

In the experiment of figure 3 , we noted that the total AChE activity $(1.05 \mathrm{OD} / \mathrm{min} / \mathrm{ml})$ was higher than expected from the values of nerve or muscle cells cultured alone, seeded at the same density as in the coculture $(0.34$ and $0.23 \mathrm{OD} / \mathrm{min} / \mathrm{ml}$ respectively). The specific activity of AChE was also increased 
in the coculture $(0.41 \mathrm{OD} / \mathrm{min} / \mathrm{mg}$ protein versus 0.3 and $0.1 \mathrm{OD} / \mathrm{min} / \mathrm{mg}$ protein in nerve and muscle cell cultures, respectively). In spite of this positive effect of the coculture on the overall AChE activity, we did not detect any A form in this case.

These experiments suggest that the expression of $A$ forms does not require a direct neural influence but is rather a property of the "late » categories of leg myoblasts (see White et al., 1975).

In the next section we examine whether the production of $A$ forms is restricted to multinucleate muscle cells or if these forms may be produced by mononucleate premuscle cells, prior to innervation.

\section{Effect of cell fusion on the expression of A forms.}

For these experiments, we used the $\mathrm{C}_{2}$ cell line derived from adult mouse muscle (Yaffe and Saxel, 1977).

The culture conditions used by $\mathrm{C}$. Pinset are indicated in the section Materials and Methods and in the legend of figure 4. We used three types of cultures:

Type 1 : medium rich in mitogenic factors in which the cells proliferate;

Type 2: medium without these factors but in which the concentration of calcium is reduced to $0.2 \mathrm{mM}$ : the cells cease to proliferate but do not fuse (no myotube was observed in these conditions);

Type 3 : medium of type 2 but the concentration of extracellular calcium is raised to $2 \mathrm{mM}$ : the cells fuse into myotubes.

We analyzed the molecular forms of $A C h E$ produced in the three types of cultures (fig. 4A, $B$ and $C$ ). In type 1 cultures, proliferating myoblasts synthesized only $G_{1}(3 S)$ and $G_{4}(10.5 S)$ forms of $A C h E$. In type 2 and 3 cultures, $A$ forms were produced $\left(A_{12}: 16.4 S, A_{8}: 13 S\right)$ in addition to $G_{1}$ and $G_{4}$ forms. The proportions of $A$ forms were however different in type 2 and 3 cultures after 3 days : they accounted for $8 \%$ of the total activity in type 2 (mononucleated cells) and $18 \%$ in type 3 (multinucleated cells). The proportion of $A$ forms increased in type 3 cultures with further differentiation (see fig. 4, D). Figure 5 shows that the $A$ forms produced in type 2 cultures were collagenase-sensitive. After $1 \mathrm{~h}$ of collagenase treatment at $20^{\circ} \mathrm{C}$, we noted that the sedimentation coefficients of $A_{12}$ form (17.4S vs $16.4 \mathrm{~S}$ in the control sample) and $A_{8}$ form (14.2S vs 13S) were increased as a result of the partial digestion of the collagen tail and that the amount of $\mathrm{G}_{4}$ form was also increased. When the collagenase treatment was performed at $37^{\circ} \mathrm{C}$ for $2 \mathrm{~h}$, we observed a total disappearance of A forms in parallel with an increase of the $G_{4}$ forms (not shown).

These experiments show that the expression of A forms of AChE in muscle cell does not require cell fusion.

\section{Discussion.}

Clonal analysis of chick myogenesis has shown that distinct classes of myoblasts (defined by their medium requirements and clonal morphology) sequentially occur during leg development (White et al., 1975). The phenotypes 

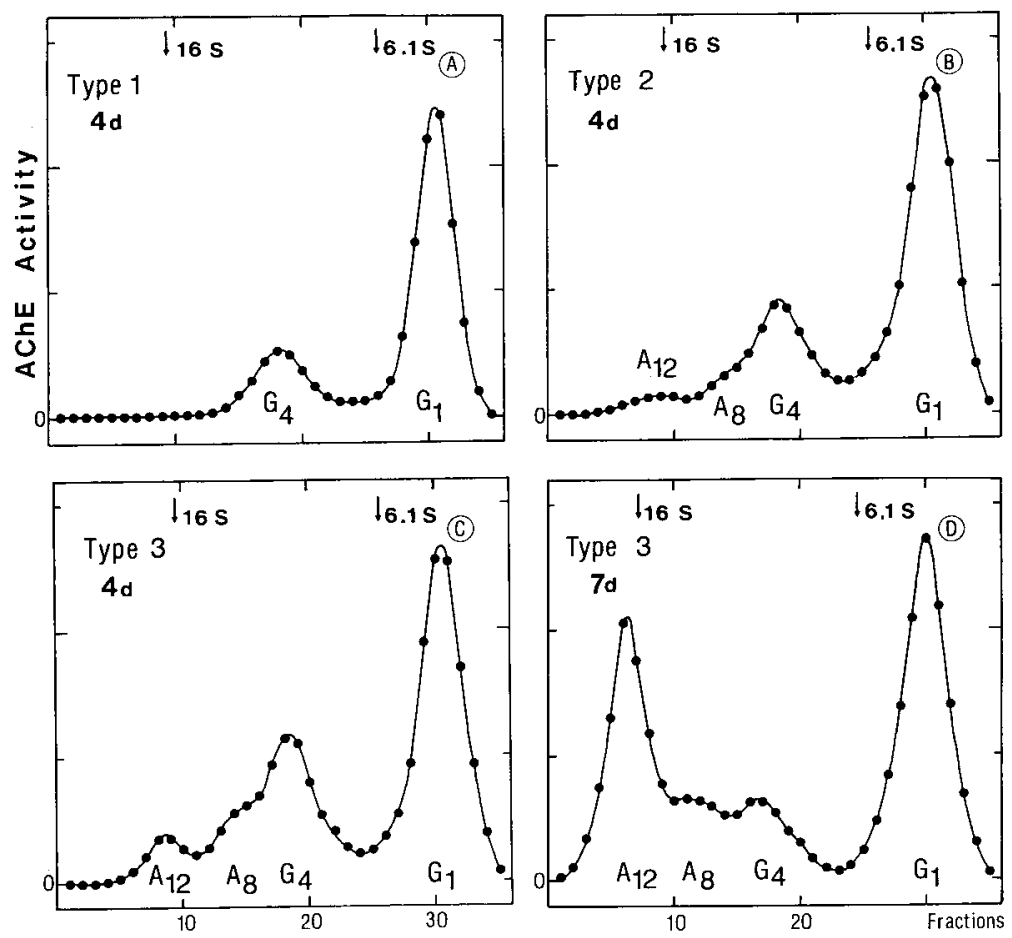

FIG. 4. - Sedimentation analysis of AChE molecular forms produced by $C_{2}$ cell in vitro. A : Type 1. Cells were cultured for 7 days in Ham's $F_{12}$ medium $+20 \%$ fetal calf serum then 4 days in the same medium. Myoblasts remain in the cell cycle $A C h E$ specific activity : $0.03 \mathrm{OD} / \mathrm{min} / \mathrm{mg}$ prot No A form. B : Type 2. Cells were cultured for 7 days in $\mathrm{Ham}$ 's $\mathrm{F}_{12}$ medium $+20 \%$ fetal calf serum then 4 days in DMEM + transferrin + insulin $+0.2 \mathrm{mM} \mathrm{Ca}^{2+}$. Cells are withdrawn from the cell cycle but do not fuse. Specific activity: $0.03 \mathrm{OD} / \mathrm{min} / \mathrm{mg}$. A forms $\left(A_{12}+A_{8}\right)$ represent $8 \%$ of the total activity. $C$ : Type 3 . Same as in $B$ but the second medium contains $2 \mathrm{mM} \mathrm{Ca}^{2+}$. Cells fuse. AChE specific activity: $0.03 \mathrm{OD} / \mathrm{min} / \mathrm{mg}$. A forms $\left(A_{12}+A_{8}\right)$ represent $18 \%$ of the total activity. D : Type 3. Same conditions as in C but cells are cultured 7 days in the DMEM medium. AChE specific activity: $0.15 \mathrm{OD} / \mathrm{min} / \mathrm{mg}$. A forms represent $50 \%$ of the total activity.

Extracts obtained in high salt medium containing $1 \% \mathrm{~T} \times 100$ were loaded on $5-20 \%$ sucrose gradient in high salt buffer containing $1 \%$ Triton $\times 100$ and centrifuged for $20 \mathrm{~h}$ at $40000 \mathrm{rpm}$ in Beckman SW41 rotor. E. coli $\beta$-galactosidase (16S) and alkaline phosphatase (6.1S) were included as internal sedimentation standards.

of these cells are maintained through subclonal passages (Rutz and Hauschka, 1982). Early and late classes of myoblasts differ by the type of myosin light chains synthesized (Toutant et al., 1984; Mouly et al., 1987). The present results indicate that the production of asymmetric forms of $\mathrm{AChE}$ by muscle cells in vitro does not depend on the presence of nerve cells but may be considered as a property of «late " classes of myoblasts. "Early " myoblasts do not synthesize A forms. Thus, AChE A forms cannot be used as a marker of neuromuscular interactions.

This conclusion is further supported by other experimental evidence obtained in vivo. Embryonic muscles in which the innervation is impaired by the early 


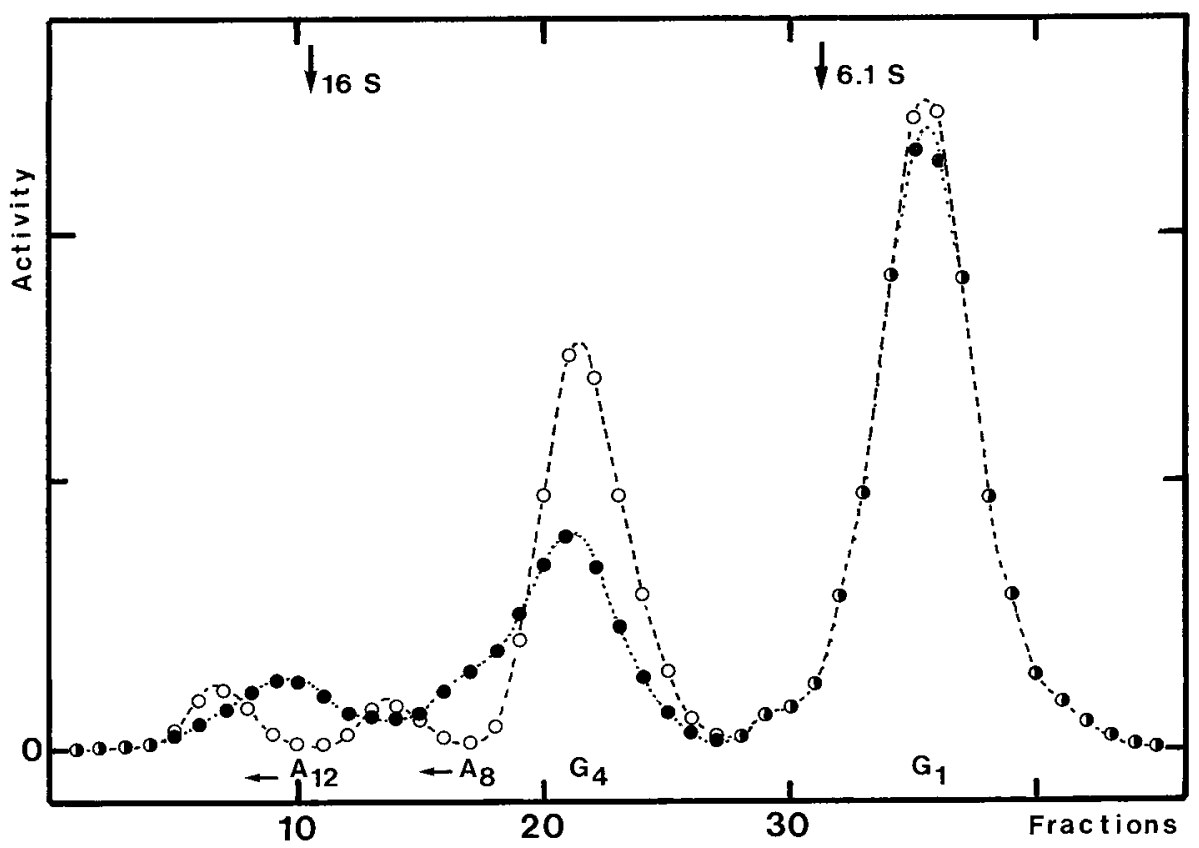

FIG. 5. - Collagenase sensitivity of asymmetric forms in $C_{2}$ cell culture of type 2. Cells were extracted in Triton-saline buffer $(1 \mathrm{M} \mathrm{NaCl}, 1 \% \mathrm{~T} \times 100) .300 \mu \mathrm{l}$ of this extract were incubated with $100 \mu \mathrm{l}$ of collagenase solution for $1 \mathrm{~h}$ at $20^{\circ} \mathrm{C}$. () or $100 \mu \mathrm{l}$ of buffer (•) and centrifuged for $20 \mathrm{~h}$ at 40 $000 \mathrm{rpm}$ at $4{ }^{\circ} \mathrm{C}$ in a Beckmann SW41 rotor. Collagenase induced an increase of the sedimentation coefficients of $A_{12}$ form (16.4S 17.6S) and $A_{8}$ form $\left(13 S \rightarrow 14.2 S\right.$ ) and the appearance of a $G_{4}$ dissociation product.

destruction of nerve cells do accumulate A forms (rat: Harris, 1981; chick : Toutant et al., 1983 ; duck : Sohal and Wrenn, 1984). In adult muscle, A forms do not always appear dependent on innervation either : these forms disappear, for example, from the innervated chick anterior latissimus dorsi muscle in aged animals (Lyles and Barnard, 1980). They are actively neosynthesized in the slow-twitch part of the rabbit semimembraneous muscle after denervation (Bacou et al., 1982) as well as in certain slow-twitch muscles in other mammals (Lai et al., 1986).

Thus the temporal correlation between the expression of $A$ forms and the establishment of innervation does not mean that the two phenomena are causally related: we suggest that it is largely coincidental.

The second purpose of this study was to investigate the synthesis of $\mathrm{AChE}$ molecular forms during early stages of muscle differentiation. Using quail myoblasts infected by a thermosensitive mutant of Rous sarcoma virus (Fiszman and Fuchs, 1975), we have previously reported that proliferating cells (cultured at $35^{\circ} \mathrm{C}$ ) synthesized only globular forms, whereas myotubes originating from the same cells (at $41 \mathrm{C}$ ) accumulated $A_{12}$ and $G$ forms (Toutant et al., 1983). Similarly, murine $\mathrm{C}_{2}$ cells have been shown to produce $A$ forms when fused into myotubes (Inestrosa et al., 1983). We show here that fusion is not a necessary condition : the $\mathrm{C}_{2}$ cells may assemble the $\mathrm{A}$ forms, even at the mononucleate state 
in culture conditions in which cells are withdrawn from the cell cycle. In these conditions, $\mathrm{C}_{2}$ mononucleated cells were also shown to accumulate muscle specific contractile proteins (C. Pinset, personal communication). This observation in vitro is supported by the recent result of Vallette et al. (1987) who reported that $A$ forms of AChE exist in dermomyotomes of 3 day-old quail embryos in which all premuscle cells are still mononucleated.

$13^{e}$ Réunion du groupe Développement I.N.R.A., Cap d'Adge, 25-27 mai 1987.

Acknowledgements. - I wish to thank Drs. M. Toutant and M. Fiszman for the gift of chick muscle cell cultures, Dr. C. Pinset for the manipulation of $C_{2}$ cell line, Dr. J. Massoulié for support and critical reading of the manuscript and Mrs. Marie-Claude Cavailhès for typing the manuscript.

Résumé. Expression des formes asymétriques de l'acéty/cholinestérase au cours de la myogenèse in vitro.

Chez le poulet, les cellules musculaires différenciées en cultures aneurales ne synthétisent des formes asymétriques d'acétylcholinestérase que si les myoblastes dont elles dérivent sont prélevés dans des muscles embryonnaires accumulant cette forme in ovo (c'est-à-dire après le $5^{\mathrm{e}}$ jour de développement embryonnaire). La présence de cellules nerveuses $n$ 'induit pas la synthèse des formes $A$ dans les cultures initiées à partir de myoblastes prélevés au $5^{e}$ jour in ovo, ni n'augmente leur proportion dans les cultures dérivant de myoblastes de 7 jours. La synthèse (ou l'assemblage?) des formes A d'AChE apparaît donc comme une propriété des catégories "tardives» de myoblastes et non comme le reflet d'une interaction nerf-muscle.

L'étude de cultures de myoblastes de la lignée cellulaire $C_{2}$ de souris suggère que la synthèse (ou l'assemblage) des formes complexes nécessite la fin des divisions cellulaires mais non la fusion: des cellules musculaires mononucléées sont donc capables, dans certaines conditions de culture, de synthétiser les formes asymétriques d'AChE.

\section{References}

BACOU F., VIGNERON P., MASSOULIE J., 1982. Acetylcholinesterase forms in fast and slow rabbit muscle. Nature, 296, 661-664.

BON S., VIGNY M., MASSOULIE J., 1979. Asymmetric and globular forms of acetylcholinesterase in mammals and birds. Proc. nat. Acad. Sci. USA, 76, 2546-2550.

BULGER J. E., RANDALL W. R., NIEBERG P. S., PATTERSON G. T., McNAMEE M. G., WILSON B. W., 1982. Regulation of acetylcholinesterase forms in quail and chicken muscle cultures. Dev. Neurosci, 5, 474-483.

FISZMAN M., FUCHS P., 1975. Temperature sensitive expression of differentiation in transformed myoblasts. Nature, 254, 429-431.

HALL Z. W., 1973. Multiple forms of acetylcholinesterase and their distribution in endplate and non-endplate regions of rat diaphragm muscle. J. Neurol., 4, 343-361.

HALL Z. W., KELLY R. B., 1971. Enzymatic detachment of endplate acetylcholinesterase from muscle. Nature New Biol., 232, 62-64.

HARRIS A. J., 1981. Embryonic growth and innervation of rat skeletal muscles. II. Neural regulation of muscle cholinesterase. Phil. Trans. Roy. Soc. Lond., 293, 280-286.

INESTROSA N. C., MILLER J. B., SILBERSTEIN L., ZISKIND-CONHAIM L., HALL Z.W., 1983. Development and regulation of $16 \mathrm{~S}$ acetylcholinesterase and acetylcholine receptors in a mouse muscle cell line. Exp. Cell Res., 147, 393-406. 
KATO A. C., VRACHLIOTIS A., FULPIUS B., DUNANT Y., 1980. Molecular forms of acetylcholinesterase in chick muscle and ciliary ganglion : embryonic tissues and cultured cells. Dev. Biol., 76, 222-228.

KOENIG J., VIGNY M., 1978. Neural induction of the $16 \mathrm{~S}$ acetylcholinesterase in muscle cell cultures. Nature, 271, 75-77.

LAI J., JEDRZEJCZYK J., PIZZEY J. A., GREEN D., BARNARD E. A., 1986. Neural control of the forms of acetylcholinesterase in slow mammalian muscles. Nature, 321, 72-74.

LANDMESSER L., MORRIS D. G., 1975. The development of functional innervation in the hind limb of the chick embryo. J. Physiol., 249, 301-326.

LYLES J. M., BARNARD E. A., 1980. Disappearance of the « endplate » form of acetylcholinesterase from a slow tonic muscle. FEBS Lett., 109, 9-12.

MASSOULIE J., BON S., 1982. The molecular forms of cholinesterase in Vertebrates. Annu. Rev. Neurosci., 5, 57-106.

MASSOULIE J., TOUTANT J. P., 1987. Cholinesterase: structure and types of interaction. In WHITTAKER V. P., The cholinergic synapse. Handbook of experimental pharmacology. Springer Verlag, Berlin. In press.

MOULY V., TOUTANT M., FISZMAN M. Y., 1987. Chick and quail limb bud myoblasts isolated at different times during muscle development, express stage-specific phenotypes when differentiated in culture. Cell Differ., 20, 17-25.

PINSET C., WHALEN R. G., 1984. Manipulation of medium conditions and differentiation in the rat myogenic cell line L6. Dev. Biol., 102, 269-277.

PINSET C., WHALEN R. G., 1985. Induction of myogenic differentiation in serum-free medium does not require DNA synthesis. Dev. Biol., 108, 284-289.

RUTZ R., HAUSCHKA S., 1982. Clonal analysis of vertebrate myogenesis. VII. Heritability of muscle colony type through sequential subclonal passages in vitro. Dev. Biol., 91, 103-110.

SOHAL G. S., WRENN R. W., 1984. Appearance of high-molecular weight acetylcholinesterase in aneural muscle developing in vivo. Dev. Biol., 101, 229-234.

TOUTANT M., MONTARRAS D., FISZMAN M. Y., 1984. Biochemical evidence for two classes of myoblasts during chick embryonic muscle development. Exp. Biol. Med., 9, 10-15.

TOUTANT J. P., 1986. An evaluation of the hydrophobic interactions of chick muscle acetylcholinesterase by charge shift electrophoresis and gradient centrifugation. Neurochem. Int., $\mathbf{9}$, $111-119$

TOUTANT J. P., MASSOULIE J., 1987. Acetylcholinesterase. In TURNER A. J., KELLY A.J., Mammalian ectoenzymes. Elsevier North Holland, Amsterdam. In press.

TOUTANT J. P., TOUTANT M., FISZMAN M. Y., MASSOULIE J., 1983. Expression of the A1 2 form of acetylcholinesterase by developing avian muscle cells in vivo and during differentiation in primary cell cultures. Neurochem. Int., 5, 751-762.

TOUTANT J. P., MASSOULIÉ J., BON S., 1985. Polymorphism of pseudocholinesterase in Torpedo marmorata tissues: comparative study of the catalytic and molecular properties of this enzyme with acetylcholinesterase. J. Neurochem., 44, 580-592.

VALLETTE F. M., VIGNY M., MASSOULIE J., 1986. Muscular differentiation of chicken myotubes in a simple defined synthetic culture medium and in serum supplemented media : expression of the molecular forms of acetylcholinesterase. Neurochem. Int., 8, 121-133.

VALLETTE F., FAUQUET M., TEILLET M., 1987. Difference in the expression of asymmetric acetylcholinesterase molecular forms during myogenesis in early avian dermomyotomes and limb buds in ovo and in vitro. Dev. Biol., 120, 77-84.

VIGNY M., KOENIG J., RIEGER F., 1976. The motor endplate specific form of acetylcholinesterase : appearance during embryogenesis and reinnervation of rat muscle. $J$. Neurochem. 27. 1347-1353.

WHITE N. K., BONNER P. H., NELSON D. R., HAUSCHKA S. D., 1975 . Clonal analysis of vertebrate myogenesis. IV. Medium-dependent classification of colony forming cells. Dev. Biol., 44, 346-361.

YAFFE D., SAXEL O., 1977. Serial passaging and differentiation of myogenic cells isolated from dystrophic mouse muscle. Nature, 270, 725-727. 